\title{
Trombositten zengin plazma
}

\author{
Platelet rich plasma
}

\author{
Cemil Yıldız', Taner Özgürtaş² \\ 'SBU Gülhane Tıp Fakültesi, Ortopedi ve Travmatoloji Anabilim Dalı, Ankara \\ ${ }^{2}$ SBU Gülhane Tıp Fakültesi, Tıbbi Biyokimya Anabilim Dalı, Ankara
}

Sınır değerinden daha yüksek trombosit konsantrasyonlardaki plazma, trombositten zengin plazma (TZP) veya diğer yaygın kullanılan ismiyle Platelet Rich Plasma (PRP) olarak adlandırılmaktadır. PRP kullanımındaki asıl amaç, trombositlerin alfa granüllerinin zengin içeriklerinin ortama tedavi amaçıı salınımının sağlanmasıdır. Trombositlerde bulunan alfa ve dens granüller ve bu granüllerin içerikleri, trombositlerin temel fonksiyonları yanında, bugün yeni tanımlanmış inflamasyon, anjiyogenez, ateroskleroz ve yara iyileşmesi gibi farklı süreçleri gerçekleştirebilmek açısından çok önemlidir. Son yıllarda, kas-iskelet yaralanmalarında ve sorunlarında PRP uygulamaları ile ilgili birçok klinik araştırmanın sonuçlarında umut verici gelişmeler belirtilmiştir. "Ne ararsan kendinde ara" özdeyişinin doğrultusunda, kendi organizmamızı tanıdıkça, daha yeni yöntem ve uygulamaların gerçekleşeceği bir dönem bizi beklemektedir.

Anahtar sözcükler: TZP; PRP; trombosit; platelet; ortopedi; tendinit; trombositten zengin plazma; kas-iskelet sistemi hastalıkları; spor yaralanmaları
Platelet Rich Plasma (PRP) is defined as plasma containing a higher concentration of platelets from their normal upper limit. The main use of PRP is the release of alfa granule-rich content of platelets into the injection site. Alfa and dens granules in platelets and the contents of these granules are important in inflammation, angiogenesis, atherosclerosis and wound healing other than their known basic functions. In recent years there are many promising developments in treating musculoskeletal injuries and diseases with PRP practices. As the famous quote "What you're searching for, search in yourself" says, it is predictable that as we learn more about our own organism there will come an era that new methods and technics are available.

Key words: PRP; thrombocyte; platelet; orthopedics; tendinitis; sports; musculoskeletal disorders; sports injuries

gerekir. Trombositin yaşlanmasıyla birlikte ortaya çıkan "desializasyon" yani sialik asidin kaybı, hücrenin dolaşımdan uzaklaştırılması için bir sinyal olarak algılanır ve retiküloendoteliyal sistem tarafindan dolaşımdan uzaklaştırılır. ${ }^{[3]}$

Hücrelerin en önemli elemanları kuşkusuz proteinlerdir. Her bir hücrenin üstlendiği görevine göre yapısında yer alan protein profili farklıdır ve bu proteinlerin hepsine, o hücrenin proteom'u adı verilir. Trombositlerde nükleus olmadığı için, protein profilinin çok sınırlı ve statik olduğu düşünülebilir. Ancak, megakaryositlerden kendilerine miras kalmış olan proteinler ve intrasitoplazmik mRNA'lar incelendiğinde, trombositlerin çok zengin bir protein profiline sahip olduğu görülür. ${ }^{[4]}$ Sonuç olarak, trombosit protein profilinin kaynağı megakaryositler ve plazmadır. ${ }^{[5]}$

- Illetişim adresi: Prof. Dr. Cemil Yıldız, SBU Gülhane Tıp Fakültesi, Ortopedi ve Travmatoloji Anabilim Dalı, Etlik, Ankara Tel: 0312 - 3045501 e-posta: cyorto@yahoo.com

- Geliș tarihi: 20 Mart 2017 Kabul tarihi: 20 Mart 2017 
Trombosit protein profili yaşla ve cinsiyetle önemli ölçüde değişiklik gösterir. ${ }^{[6]}$ Sağlıklı kişilerin de trombosit protein profili hastalıklarda kısmen değişikliklere uğrar. Hatta, sigara içenlerle içmeyenler arasında da protein spektrumu, trombosit fonksiyonları açısından önemli farklılıklar içermektedir. ${ }^{[7]} \mathrm{Bu}$ da, uygulanacak Trombositten Zengin Plazma (TZP) ya da diğer bir yaygın kullanılan ismi ile PRP (Platelet Rich Plasma) uygulamalarında ortaya çıkan hasta yanıtının niçin birbirinden farklı olduğunu kısmen açıklayabilir. Ancak, daha bilmediğimiz birçok noktaların olduğu aşikardır.

\section{TROMBOSIT GRANÜLLERI VE GÖREVLERi}

Trombositten zengin plazma kullanımındaki asıl amaç, trombositlerin alfa granüllerinin zengin içeriklerinin ortama tedavi amaçlı salınımının sağlanmasıdır. Bundan dolayı, trombosit granülleri ve işlevleri hakkında biraz daha ayrıntılı bilgi edinmemizde yarar vardır.

Trombositler ışık mikroskobu ile gözlemlenebilirlerse de, yapısal özelliklerinin ortaya konulabilmesi için elektron mikroskobu gereklidir. İlk olarak 1966 yılında dens granüller tanımlanmıştır. Bundan yaklaşık bir yıl sonra ise alfa granüller'in varlığı gösterilmiştir. ${ }^{[8]} \mathrm{Ne}$ var ki, alfa granüllerle lizozomlar arasındaki net fark, sitokimyadaki gelişmelerle, ancak 1980 yılından sonra ortaya konulabilmiştir (Tablo 1). ${ }^{[9]}$

Trombositlerde bulunan alfa ve dens granüller ve bu granüllerin içerikleri, trombositlerin temel fonksiyonları yanında, bugün yeni tanımlanmış inflamasyon, anjiyogenez, ateroskleroz ve yara iyileşmesi gibi farklı süreçleri gerçekleştirebilmek açısından çok önemlidir. 2007'de alfa granüllerle yapılan bir çalışmada, 200 'den fazla protein tanımlanmıştır. ${ }^{10]}$ Dens granüllerle yapılan çalışmada ise, 40'tan fazla proteinin varlığı ortaya konulmuş ve bunların glikolizde önemli proteinler ve regülasyonda rol alan elemanlar olduğu gösterilmiştir. ${ }^{[11]}$ Koagülasyon, inflamasyon, remodeling gibi kimi süreçler, trombositleri aktive ederek protein sentezinin miktarını ve niteliğini değiştirmektedir.

Trombosit sitoplazmasında gözlenen farklı granüller ve bunların sekretuvar (salınım) görevleri aşağıda özetlenmiştir:

- Alfa granüller; sadece trombositlere özgün ve en yüksek sayıda bulunan granül formudur. Granüllerin çapı 200-500 nm civarındadır. Bazen dev granüllere rastlanır, ancak bu uzun süreli in vitro saklama sonucu oluşmaktadır. Alfa granüller, çok sayıda protein içerir. Bunlardan bir kısmı megakaryositlerden miras olarak gelmektedir. Örnek olarak; koagülasyon faktör $\mathrm{V}$, trombospondin, P-selektin, vWF (von Willebrand faktör) sayılabilir. Fibrinojen gibi bazı proteinler ise plazmadan granül içine transfer edilmektedir.

- Dens granüller; alfa granüllerden daha küçüktür ve trombosit içinde daha az sayıdadır. Dens granüllerin içerikleri, adenin nükleotidleri, ATP, ADP, serotonin, pirofosfat, kalsiyum ve magnezyumdur.

- Lizozomlar; alfa granüllerden daha küçük ve genelde trombosit başına 1-3 adet izlenir. Lizozomlar en az 13 asit hidrolaz içerir, bunlardan en önemlileri arasında, katepsin D-E, WAMP-1, LAMP2 ve CD63 sayılabilir.

\section{TROMBOSITTEN ZENGIN PLAZMA (TZP) UYGULAMA ALANLARI}

Trombositten zengin plazma (TZP) veya diğer yaygın kullanılan ismiyle Platelet Rich Plasma (PRP), sınır değerinden daha yüksek trombosit konsantrasyonlardaki plazmanın adıdır, ancak bu sınır değer için net bir tanımlama bulunmadığından, ortalama artış "dört kat" olarak kabul edilmektedir. Illk olarak 1987 yılında kalp cerrahları tarafından kullanılmıştır. ${ }^{[12]}$ Uzun bir aradan sonra 2000'li yıllarda, PRP kullanımı maksillofasyal

Tablo 1. Trombosit granüllerinin içerikleri

\begin{tabular}{ll}
\hline Alfa granül içerikleri & Dens granül içerikleri \\
\hline Integral membran proteinleri & Katyonlar \\
Koagülasyon sistemi proteinleri & Fosfatlar \\
Adhezyon proteinleri & Biyoaktif aminler \\
Kemokinler & Nükleotidler \\
Büyüme faktörleri & \\
Pro-anjiyojenik ve Anti-anjiyojenik faktörler & \\
Mikrobiyolojik proteinler &
\end{tabular}


cerrahlar tarafindan bir kez daha güncel olarak ortaya konmuştur. ${ }^{[13]}$ Ancak, 2012 yılındaki FDA onayı ile, PRP birçok kas iskelet sistemini ilgilendiren sorunlarda yaygın olarak kullanılmaya başlanmıştır. ${ }^{14]}$

Son yıllarda PRP uygulamaları ile ilgili birçok klinik araştırma yapılmış ve sonuçları yayımlanmaya başlamıştır (Tablo 2). Erken dejenerasyonu olan ve osteoartrit gelişen dizlerde PRP uygulaması ile, 6 ve 12 aylık takiplerde, International Knee Documentation Committee (IKDC) skorlarında istatistiksel olarak anlamlı bir gelişme olduğu gösterilmiştir. ${ }^{[15]}$ PRP ve hiyaluronik asit (HA) enjeksiyonlarını karşılaştıran

Tablo 2. Trombositten zengin plazma uygulamaları ile ilgili son yıllardaki bazı klinik seriler

\begin{tabular}{|c|c|c|c|c|c|c|}
\hline Yazar & $\begin{array}{l}\text { Çalışmanın } \\
\text { tipi }\end{array}$ & $\begin{array}{l}\text { Hasta } \\
\text { grubu }\end{array}$ & $\begin{array}{l}\text { Klinik takip } \\
\text { şekli ve süresi }\end{array}$ & Hasta sayısı & Tedavi & Sonuçlar \\
\hline $\begin{array}{l}\text { Hoon Lee } \\
\text { ve ark. 2014[28] }\end{array}$ & $\begin{array}{l}\text { Illeriye dönük } \\
\text { randomize } \\
\text { kontrollü }\end{array}$ & $\begin{array}{l}\text { Bilateral tibia } \\
\text { uzatma operasyonu } \\
\text { planlanan hastalar }\end{array}$ & $\begin{array}{l}\text { Ortalama } 28 \\
\text { ay takip }\end{array}$ & $\begin{array}{l}22 \text { hastanın } 44 \\
\text { tibiası }\end{array}$ & $\begin{array}{l}\text { BMAC + } \\
\text { PRP }\end{array}$ & $\begin{array}{l}\text { Ortalama kortikal iyileşme indeksi } \\
\text { tedavi grubunda kortikal kemikte } \\
\text { daha hızlı iyileşme izlenmiş̧ } \\
\text { ve daha erken yük verildiği } \\
\text { bildirilmiştir. }\end{array}$ \\
\hline $\begin{array}{l}\text { Namazi ve ark. } \\
2015^{[29]}\end{array}$ & $\begin{array}{l}\text { Illeriye dönük } \\
\text { randomize } \\
\text { kontrollü }\end{array}$ & $\begin{array}{l}\text { Eklem içi radius } \\
\text { distal uç kırığı } \\
\text { bulunan kapalı } \\
\text { redüksiyon } \\
\text { perkütan pinleme } \\
\text { yapılan hastalar } \\
\text { (Frykman Tip: } 3 \text {, } \\
4,7,8 \text { ) }\end{array}$ & Altı ay, PRWE & 30 hasta & PRP & $\begin{array}{l}\text { Ağrı skoru, genel ve spesifik } \\
\text { aktivite skorlarında } 3 \text { ve } 6 \text { aylık } \\
\text { takiplerde PRP enjeksiyonu yapılan } \\
\text { grupta belirgin ilerleme olduğu } \\
\text { bildirilmiştir. }\end{array}$ \\
\hline $\begin{array}{l}\text { Karaduman } \\
\text { ve ark. } 2016^{[30]}\end{array}$ & Geriye dönük & $\begin{array}{l}\text { Kronik lateral } \\
\text { epikondilit } \\
\text { tanısı alan PRP } \\
\text { enjeksiyonu veya } \\
\text { Nirschl tekniği } \\
\text { ile opere edilen } \\
\text { hastalar }\end{array}$ & $\begin{array}{l}\text { Şubat } 2011 \text { ile } \\
\text { Aralık } 2012 \text { yılı } \\
\text { arasında tedavi } \\
\text { edilen hastalar. } \\
\text { VAS, Mayo } \\
\text { dirsek skoru, } \\
\text { kavrama gücü } \\
\text { ölçümleri }\end{array}$ & $\begin{array}{l}50 \text { Cerrahi } \\
\text { uygulanan, } 60 \\
\text { PRP uygulanan } \\
\text { hasta }\end{array}$ & $\begin{array}{l}\text { PRP ve } \\
\text { cerrahi }\end{array}$ & $\begin{array}{l}\text { PRP enjeksiyonu yapılan hastaların } \\
\text { kısa ve orta süreli takiplerinde } \\
\text { ağrı ve fonksiyonel degerlendirme } \\
\text { sonuçlarının daha iyi olduğu } \\
\text { bildirilmiştir. }\end{array}$ \\
\hline $\begin{array}{l}\text { Kesikburun } \\
\text { ve ark. } 2013^{[31]}\end{array}$ & $\begin{array}{l}\text { Illeriye dönük } \\
\text { randomize } \\
\text { kontrollü }\end{array}$ & $\begin{array}{l}\text { Üç aydan uzun } \\
\text { süredir omuz } \\
\text { ağrısı olan, MR } \\
\text { görüntülemede } \\
\text { rotator manşet } \\
\text { yırtığı ya da } \\
\text { parsiyel tendon } \\
\text { yırtığı bulunan } \\
\text { ve subakakromiyal } \\
\text { anestezik } \\
\text { enjeksiyonlarından } \\
\text { sonra ağrısında \%50 } \\
\text { den fazla azalma } \\
\text { izlenen hastalar }\end{array}$ & $\begin{array}{l}\text { WORC, SPADI, } \\
\text { VAS, bir yıllık } \\
\text { takip }\end{array}$ & $\begin{array}{l}20 \text { PRP } \\
\text { uygulanan, } \\
20 \text { plasebo } \\
\text { uygulanan } \\
\text { hasta }\end{array}$ & $\begin{array}{l}\text { PRP ve } \\
\text { plasebo }\end{array}$ & $\begin{array}{l}\text { Bir yıllık takip sonrasında PRP } \\
\text { uygulanan grupta yaşam kalitesi, } \\
\text { ağrı, omuz hareket açıklığı } \\
\text { değerlerinde plasebo grubundan } \\
\text { belirgin fark saptanmadığı } \\
\text { bildirilmiştir. }\end{array}$ \\
\hline $\begin{array}{l}\text { Güney ve ark. } \\
2013^{[32]}\end{array}$ & Klinik çalışma & $\begin{array}{l}\text { Talus osteokondral } \\
\text { lezyonu bulunan } \\
\text { hastalar }\end{array}$ & $\begin{array}{l}\text { AOFAS, FAAM, } \\
\text { VAS }\end{array}$ & $\begin{array}{l}16 \text { hasta } \\
\text { sadece } \\
\text { mikrokırık } \\
\text { tekniği ile } \\
\text { tedavi, } 19 \\
\text { hastaya ek } \\
\text { olarak PRP } \\
\text { uygulanmış, } \\
\text { toplam } 35 \\
\text { hasta }\end{array}$ & $\begin{array}{l}\text { Cerrahi ve } \\
\text { cerrahi + PRP }\end{array}$ & $\begin{array}{l}\text { Cerrahi + PRP uygulanan grupta } \\
\text { VAS skorlarında artış saptansa } \\
\text { da orta dönem fonksiyonel } \\
\text { sonuçlarda anlamlı ilerleme } \\
\text { olduğu bildirilmiştir. }\end{array}$ \\
\hline $\begin{array}{l}\text { Riboh ve ark. } \\
2016^{[33]}\end{array}$ & Meta-analiz & $\begin{array}{l}\text { Diz osteoartritli } \\
\text { hastalarda }\end{array}$ & $\begin{array}{l}\text { WOMAC, } \\
\text { IKDC, }\end{array}$ & $\begin{array}{l}1055 \text { hasta } \\
\text { LR-PRP ve } \\
\text { LP-PRP yapılan } \\
\text { hastalar } \\
\text { karşılaştırılmış. }\end{array}$ & $\begin{array}{l}\text { LR-PRP, } \\
\text { LP-PRP }\end{array}$ & $\begin{array}{l}\text { LP-PRP uygulanan hastalarda } \\
\text { HA ve plasebo uygululanan } \\
\text { gruplara göre daha iyi fonksiyonel } \\
\text { sonuçlar elde edilmiş, LR-PRP } \\
\text { ve LP-PRP arasında anlamlı fark } \\
\text { saptanmadığı bildirilmiştir. }\end{array}$ \\
\hline $\begin{array}{l}\text { Napolitano } \\
\text { ve ark. } 2012^{[34]}\end{array}$ & Olgu serisi, & $\begin{array}{l}\text { Bir yıldan uzun } \\
\text { süredir dejeneratif } \\
\text { eklem hastalığı } \\
\text { tanısı ile takip } \\
\text { edilen hastalar }\end{array}$ & $\begin{array}{l}\text { NRS, WOMAC, } \\
6 \text { ay takip }\end{array}$ & $\begin{array}{l}18-81 \text { yaş arası } \\
27 \text { hasta }\end{array}$ & PRP & $\begin{array}{l}\text { Altı aylık takip sonunda } \\
\text { parametrelerde ilerleme saptanmış } \\
\text { ve ilk enjeksiyon sonrası ağrıda } \\
\text { gerileme olduğu bildirilmiştir. }\end{array}$ \\
\hline
\end{tabular}


Tablo 2 (devam). Trombositten zengin plazma uygulamaları ile ilgili son yıllardaki bazı klinik seriler

\begin{tabular}{|c|c|c|c|c|c|c|}
\hline Yazar & $\begin{array}{l}\text { Çalış̧manın } \\
\text { tipi }\end{array}$ & $\begin{array}{l}\text { Hasta } \\
\text { grubu }\end{array}$ & $\begin{array}{l}\text { Klinik takip } \\
\text { şekli ve süresi }\end{array}$ & Hasta sayısı & Tedavi & Sonuçlar \\
\hline $\begin{array}{l}\text { Laudy ve ark. } \\
2015^{[35]}\end{array}$ & $\begin{array}{l}\text { Sistematik } \\
\text { derleme ve } \\
\text { meta-analiz }\end{array}$ & $\begin{array}{l}\text { On çalışma dahil } \\
\text { edilmiştir. }\end{array}$ & $\begin{array}{l}\text { Ort. } 6 \text { ay takip, } \\
\text { VAS, NRS }\end{array}$ & & $\begin{array}{l}\text { PRP, HA, } \\
\text { plasebo }\end{array}$ & $\begin{array}{l}\text { Çalışmaların neredeyse tümünde } \\
\text { PRP enjeksiyonunun plasebo ve } \\
\text { Hyalüronik asit enjeksiyonlarından } \\
\text { ağrıyı azaltma açısından üstün } \\
\text { olduğu fakat neredeyse tümünde } \\
\text { yüksek bias riski saptandığı } \\
\text { bildirilmiştir. }\end{array}$ \\
\hline $\begin{array}{l}\text { Wichan } \\
\text { Kanchanatawan } \\
\text { ve ark. 2016[36] }\end{array}$ & $\begin{array}{l}\text { Yedi } \\
\text { randomize } \\
\text { kontrollü } \\
\text { çalışma }\end{array}$ & $\begin{array}{l}\text { Sistematik derleme } \\
\text { ve meta-regresyon }\end{array}$ & $\begin{array}{l}\text { WOMAC, } \\
\text { IKDC, KOOS, } \\
\text { Lequesne }\end{array}$ & & $\begin{array}{l}\text { PRP, HA, } \\
\text { plasebo }\end{array}$ & $\begin{array}{l}\text { PRP enjeksiyon grubunda } \\
\text { HA enjeksiyon grubuna göre } \\
\text { düşük ortalama WOMAC } \\
\text { skoru saptanırken, IKDC ve } \\
\text { EQ-VAS skorlarında yükselme } \\
\text { saptanmışstır. PRP enjeksiyon } \\
\text { grubu ile HA enjekte edilen } \\
\text { grup ve plasebo grubu arasında } \\
\text { WOMAC, Lequesne skorları ve } \\
\text { yan etkiler açısından anlamlı fark } \\
\text { saptanmadığı bildirilmiştir. }\end{array}$ \\
\hline $\begin{array}{l}\text { Spaková ve ark. } \\
2012^{[18]}\end{array}$ & $\begin{array}{l}\text { Illeriye dönük, } \\
\text { kohort }\end{array}$ & $\begin{array}{l}1,2,3 \text { derece } \\
\text { osteoartrit } \\
\text { hastaları, } 3-6 \text { ay } \\
\text { takip }\end{array}$ & WOMAC, NRS & 120 hasta & PRP, HA & $\begin{array}{l}\text { PRP enjeksiyonu yapılan grupta } \\
\text { WOMAC ve NRS skorlarında } \\
\text { gelişme saptanırken herhangi } \\
\text { bir yan etki saptanmadığı } \\
\text { bildirilmiştir. }\end{array}$ \\
\hline $\begin{array}{l}\text { Filardo ve ark. } \\
2012^{[37]}\end{array}$ & $\begin{array}{l}\text { Ileriye dönük } \\
\text { randomize }\end{array}$ & $\begin{array}{l}\text { Semptomatik } \\
\text { dejeneratif artrit ve } \\
\text { osteoartrit, } 2,6,12 \\
\text { aylık takip }\end{array}$ & $\begin{array}{l}\text { IKDC, KOOS, } \\
\text { EQ-VAS }\end{array}$ & 144 hasta & PRP, PRGF & $\begin{array}{l}\text { PRP ile PRGF yöntemi } \\
\text { kaşılaştırılmış. Her iki yöntemde } \\
\text { tüm skorlarda ilerlerme } \\
\text { kaydedilmiş genç ve daha az } \\
\text { kartilaj dejenerasyonu olan } \\
\text { hastalarda daha iyi sonuçlar } \\
\text { alınmış. iki yöntem arasında } \\
\text { PRP'nin biraz daha fazla şş̧lik } \\
\text { ve ağrı yapmasıs dışında fark } \\
\text { saptanmamıştır. }\end{array}$ \\
\hline $\begin{array}{l}\text { Jubert ve ark. } \\
2017^{[38]}\end{array}$ & $\begin{array}{l}\text { Ileriye dönük } \\
\text { randomize }\end{array}$ & $\begin{array}{l}\text { Semptomatik diz } \\
\text { OA 1, 3, } 6 \text { aylık } \\
\text { takip }\end{array}$ & VAS, KOOS & 75 hasta & $\begin{array}{l}\text { PRP, } \\
\text { Steroid + } \\
\text { lokal } \\
\text { anestezik }\end{array}$ & $\begin{array}{l}\text { PRP ile LA + steroid enjeksiyonu } \\
\text { karşılaştırılmış, iki grupta da tüm } \\
\text { değişkenlerde gelişme saptanmış, } \\
\text { sonuçların çoğunda iki grup } \\
\text { arasında istatistiksel anlamlı fark } \\
\text { bulunmamıştır. }\end{array}$ \\
\hline $\begin{array}{l}\text { Randelli ve ark. } \\
2011^{[39]}\end{array}$ & $\begin{array}{l}\text { Illeriye dönük } \\
\text { randomize } \\
\text { kontrollü }\end{array}$ & $\begin{array}{l}\text { Tam kat rotator } \\
\text { manşet yırtığı } \\
\text { nedeniyle omuz } \\
\text { artroskopisi } \\
\text { planlanan hastalar } \\
\text { (iki yıl takip) }\end{array}$ & $\begin{array}{l}\text { SST, UCLA } \\
\text { ve dinamik } \\
\text { ölçümler }\end{array}$ & 53 hasta & PRP & $\begin{array}{l}\text { 3, } 7,14 \text { ve } 30 \text {. günlerde artroskopi } \\
\text { sırasında PRP uygulanan grupta } \\
\text { uygulanmayan gruba göre ağrı } \\
\text { skoru daha düşük saptanmış, } \\
\text { SST, UCLA ve dinamik olçüm } \\
\text { skorları üç aylık takipte tedavi } \\
\text { grubu daha yüksek bulunmuş. İki } \\
\text { yıllık takipler sonunda iki grup } \\
\text { arasında testler arasında belirgin } \\
\text { fark saptanmamış. sadece Grade } \\
1-2 \text { yırtığı olan grupta dış rotasyon } \\
\text { kuvveti daha yüksek saptanmıştır. }\end{array}$ \\
\hline $\begin{array}{l}\text { De Vos ve ark. } \\
2010^{[40]}\end{array}$ & $\begin{array}{l}\text { Randomize } \\
\text { plasebo } \\
\text { kontrollü tek } \\
\text { merkezli }\end{array}$ & $\begin{array}{l}18-70 \text { yaş arası } \\
\text { kronik Aşil tendinitli } \\
\text { hastalar } \\
\text { Egzersiz tedavisi + } \\
\text { serum fizyolojik ya } \\
\text { da PRP enjeksiyonu }\end{array}$ & VISA-A & $\begin{array}{l}18-70 \text { yaş arası } \\
54 \text { hasta }\end{array}$ & $\begin{array}{l}\text { PRP } \\
\text { Plasebo }\end{array}$ & $\begin{array}{l}\text { Yirmi dört haftalık takipte iki } \\
\text { grup arasında ağrı ve aktivite } \\
\text { skorlarında belirgin fark } \\
\text { saptanmamıştır. }\end{array}$ \\
\hline $\begin{array}{l}\text { Lebiedzinski ve } \\
\text { ark. } 2015^{[41]}\end{array}$ & $\begin{array}{l}\text { Ileriye dönük } \\
\text { randomize } \\
\text { kontrollü }\end{array}$ & $\begin{array}{l}\text { Kronik lateral } \\
\text { epikondilit tanılı } \\
\text { hastalar }\end{array}$ & DASH & 99 hasta & $\begin{array}{l}\text { Autologous } \\
\text { conditioned } \\
\text { plasma ve } \\
\text { betametazon } \\
\text { enjeksiyonu }\end{array}$ & $\begin{array}{l}\text { Bir yıllık takiplerde betametazon } \\
\text { grubu daha hızlı iyileşme sağlasa } \\
\text { da ACP enjeksiyonu uygulanan } \\
\text { grupta oluşan tedavi edici etkinin } \\
\text { daha kalıcı olduğu saptanmıştır. }\end{array}$ \\
\hline
\end{tabular}

PRP, trombositten zengin plasma; HA, hyaluronik asit; WOMAC, the Western Ontario and McMaster Universities Osteoarthritis Index;

NRS, numerical rating scale; SST, simple shoulder test; UCLA, University of California; IKDC, the International Knee Documentation Committee;

EQ-VAS, EuroQol-visual analogue scales; KOOS, knee injury and osteoarthritis outcome score;

VISA-A, the Victorian Institute of Sports Assessment - Achilles questionnaire; DASH, the disabilities of the arm, shoulder and hand;

PRWE, patient-rated wrist evaluation; AOFAS, American Orthopaedic Foot and Ankle Society; FAAM, foot and ankle ability measure. 
çalışmada, ağrının ve semptomların azalması konusunda PRP sonuçlarının daha iyi olduğu saptanmıştır. ${ }^{[16]}$ Bir başka iki yıllık takibi olan çalışmada, dizdeki dejenerasyonun tedavisinde PRP'nin etkili olduğu gösterilmektedir; benzer sonuçlar diğer çaIışmalarda da alınmıştır. ${ }^{[17-19]}$ Yaşlılara kıyasla gençlerde ve şiddetlilere kıyasla daha hafif olgularda, PRP ile daha iyi sonuçlar almanın mümkün olduğu değerlendirilmektedir. ${ }^{[20]}$ Son yayınlarda, diz osteoartiritinin erken dönemlerinde uygulanan PRP'nin, en az bir yıllık bir dönem için şikayetlerde azalma sağladığı belirtilmektedir. ${ }^{[21,22]}$ Ayrıca, lökosit-fakir PRP ile lökosit-zengin PRP'nin etkilerinin benzer olduğu ve lökosit konsantrasyonuna bağlı farklı etkiler gözlenmediği, yapılan bir çalışmayla gösterilmiştir. ${ }^{[23]}$ Biz de, kas-iskelet sistemini ilgilendiren birçok sorunda PRP uygulamaktayız (örn; avasküler nekroz, tendinitler, spor yaralanmalan, osteoartrit, yara iyileşmesi, kırık kaynama gecikmesi) (Şekil 1-6).
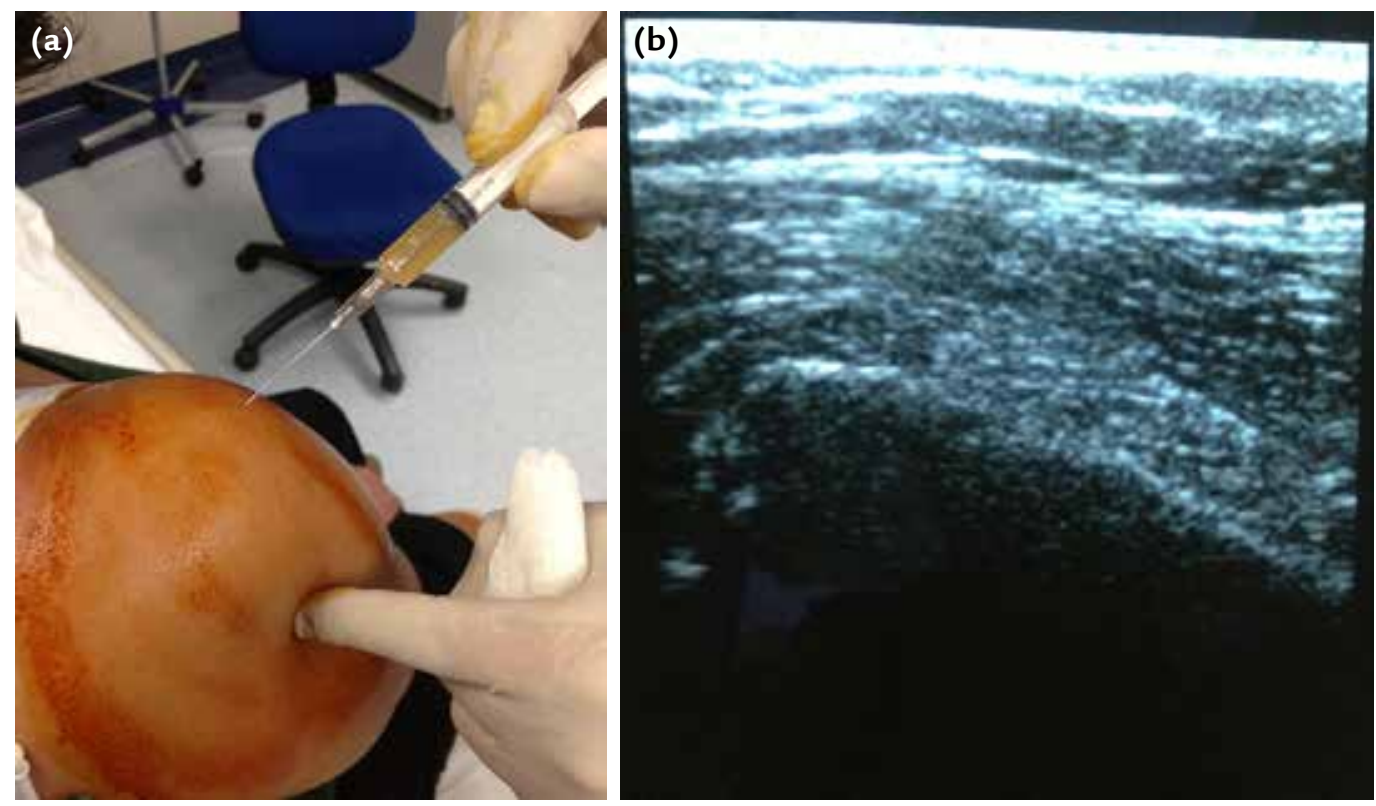

Şekil 1. a, b.

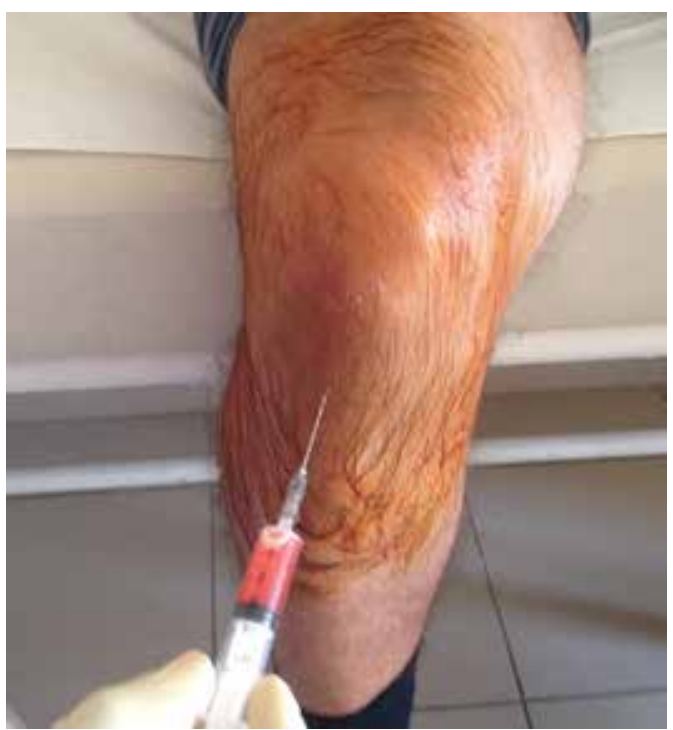

Şekil 2.

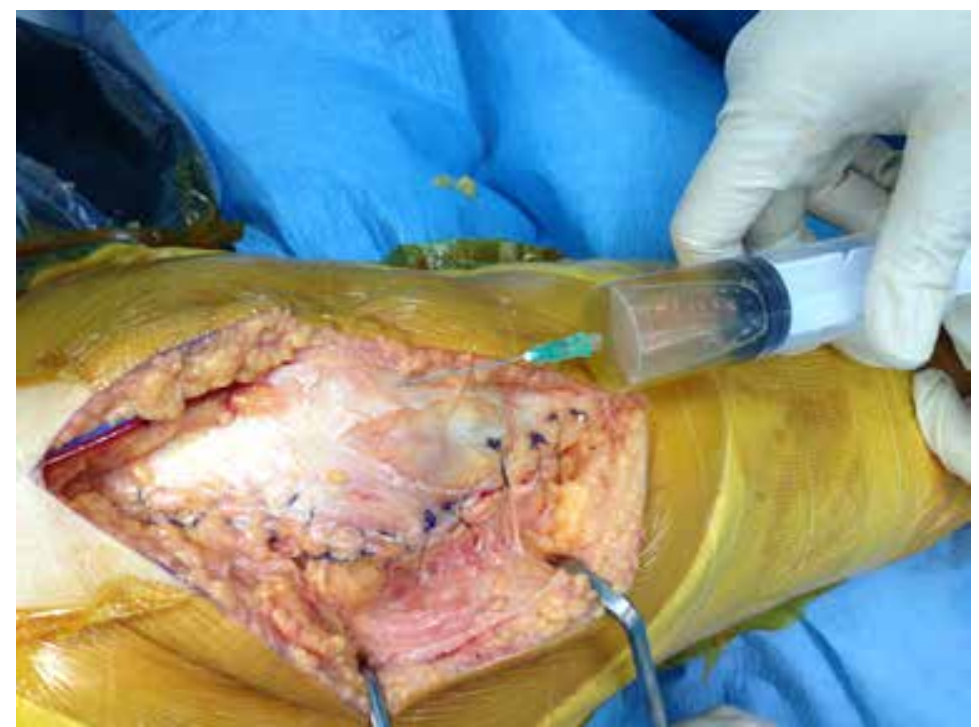

Şekil 3. 

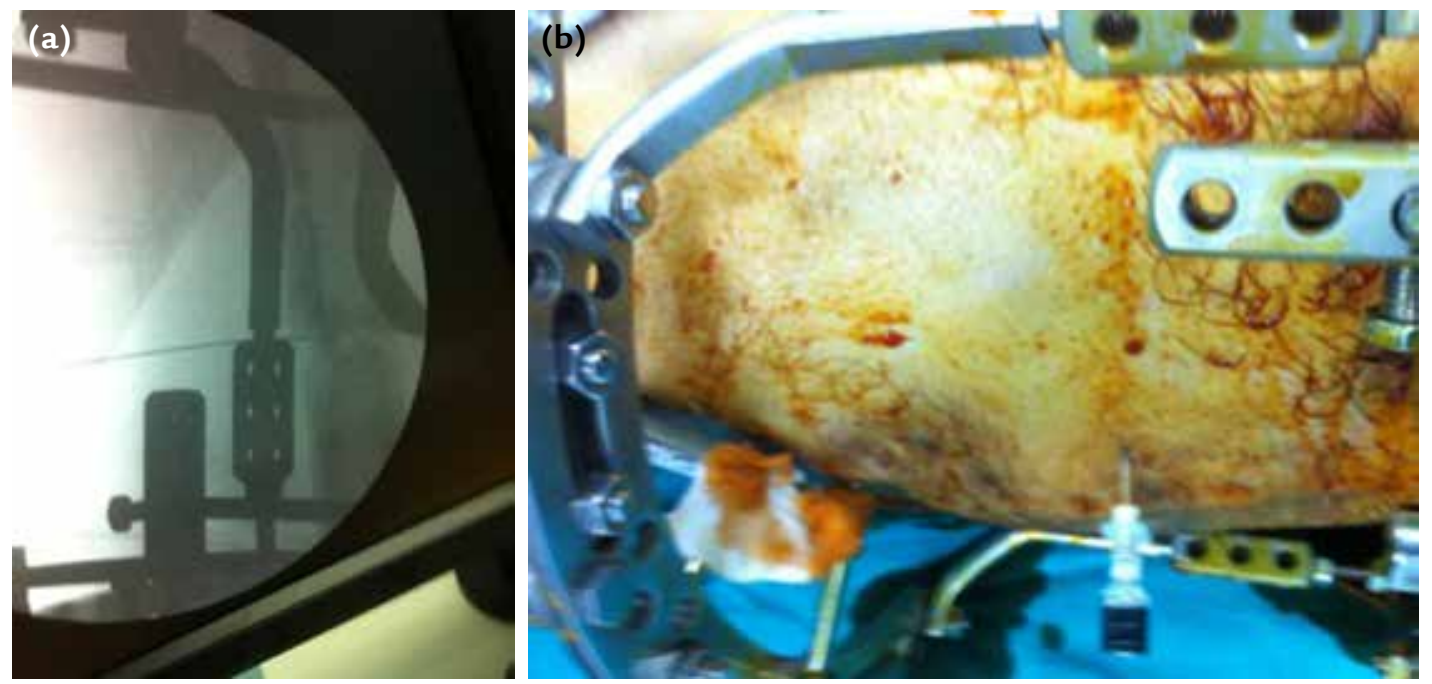

Şekil 4. a, b.
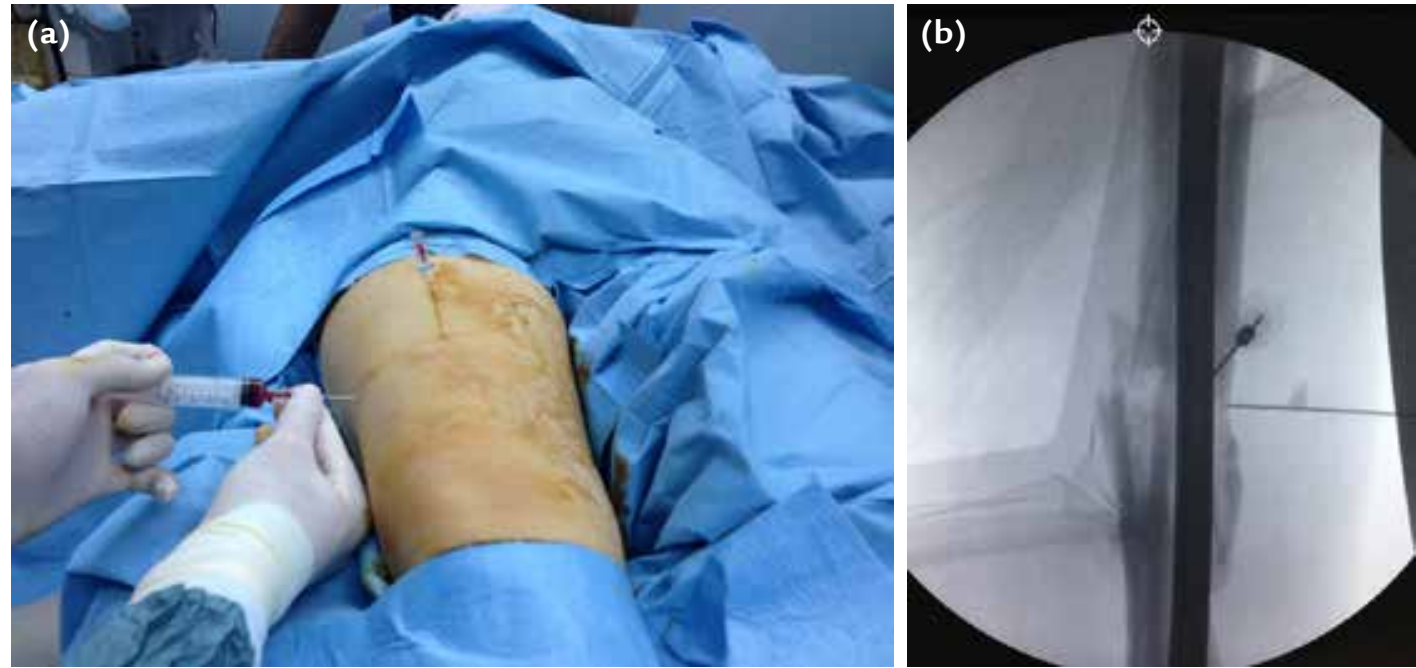

Şekil 5. a, b.
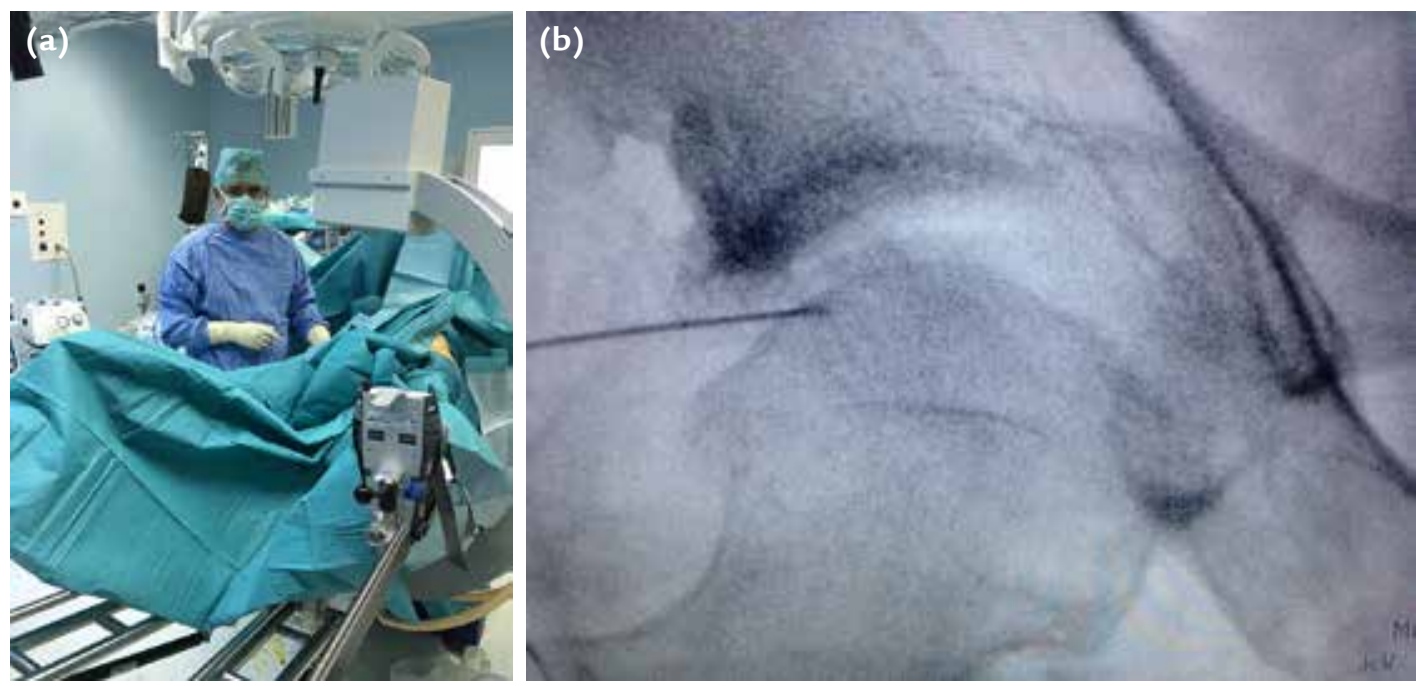

Şekil 6. a, b. 

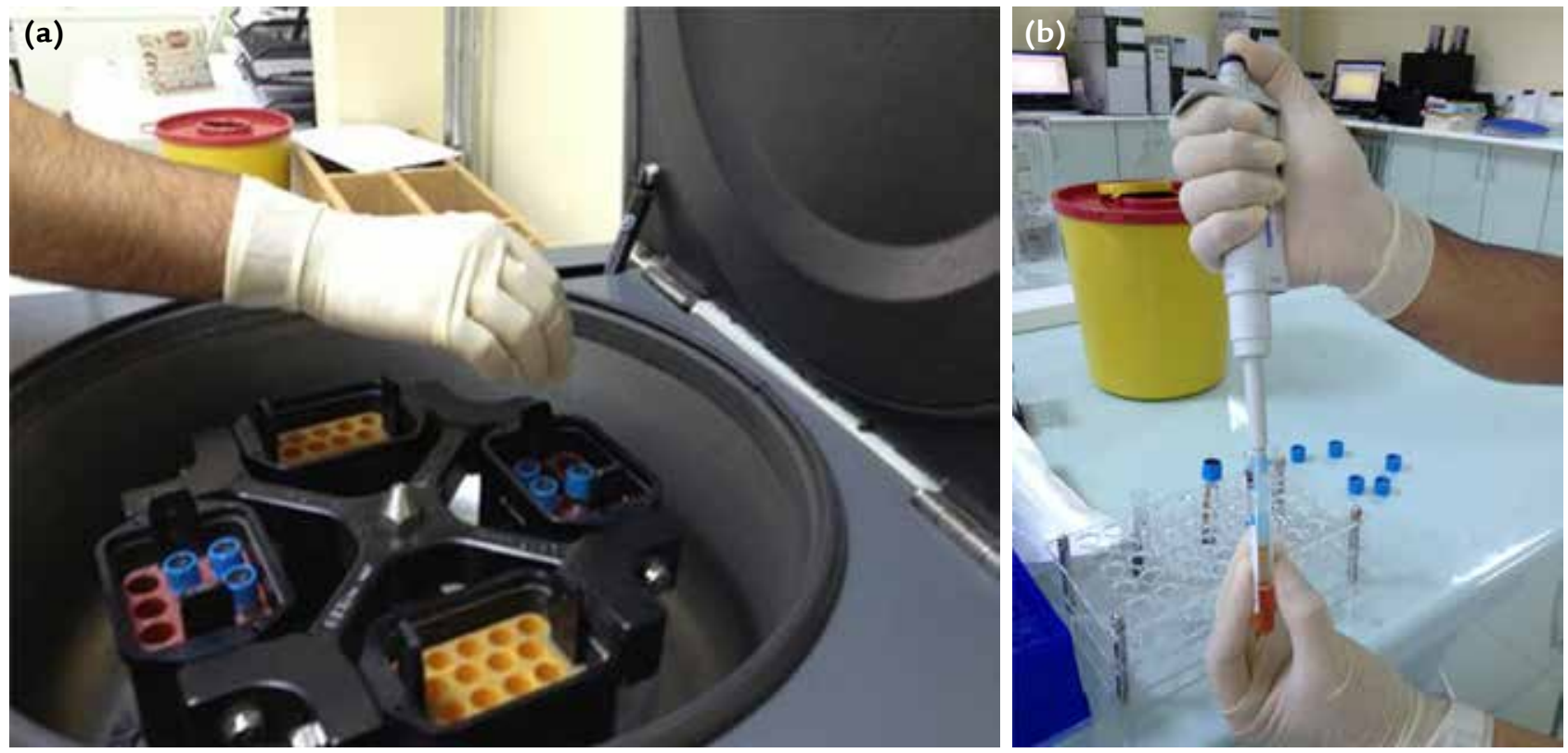

Şekil 7. a, b. Kendi yöntemimize göre (TPE: 2013/11293) laboratuvarda L-PRP hazırlanışı görülmektedir.

\section{TROMBOSITTEN ZENGIN PLAZMA HAZIRLANMASI VE ÇEŞiTLERI}

PRP, steril koşullarda ve laboratuvar ortamında hazırlanmalıdır (Şekil 7). Ayrıca, PRP hazırlanması ile ilgili birçok ticari PRP kiti bulunmaktadır. Tablo 3'te bunlardan bazıları ayrıntılı olarak karşılaştırılmıştır. Her sistemin avantaj ve dezavantajları vardır. Kendi klinik tecrübemize göre, bunlara dikkat edilerek kullanılmadığı takdirde, istenilen verimliliğe ulaşılamamaktadır.

Bugün kabul edilen başlıca dört temel trombositten zengin plazma ürünü ve hazırlama yaklaşımı vardır[24] (Tablo 4):

- Pure Platelet Rich Plasma (P-PRP): Bu yöntem, lökositten arındırılmış saf trombosit eldesini tanımlar ve bunun için plazmaferez gibi 'hücre ayırıcılar' kullanılır. Bu yaklaşımda, lökosit sayısı normale göre sıfır veya çok düşüktür. Ancak, diğer yöntemlere göre uygulanması zor ve çok daha pahalıdır.

- Lökosit ve Platelet Rich Plasma (L-PRP): Özel ayırıcı cihazlar yerine, çok daha kolay bir santrifüj yöntemiyle, trombositlerle birlikte lökositler eritrositlerden ayrıştırılır. Biz de bu yöntemi ilk defa 2005 yılında kullanarak, sıçanların siyatik sinir lezyonlarında PRP ve büyüme faktörlerinin etkilerini deneysel olarak karşılaştırdık. ${ }^{[25]}$
- Pure Platelet Rich Fibrin (P-PRF): Bu yöntem, L-PRP'ye benzemekle birlikte, separatörlü ilk santrifüj sonrasında, eklenen $\mathrm{CaCl}$ ile birlikte ikinci santrifüj basamağı sırasında stabil platelet-fibrin pıhtı eldesine dayanır. Bu yönteme özgünlügüüü veren, separasyon jelinin varlığıdır.

- Lökosit ve Platelet Rich Fibrin (L-PRF): Basit ve ucuz bir yöntemdir; cam tüplere alınan kan örneklerine, herhangi bir antikoagülan kullanılmadan düşük süratte hemen santrifüj uygulanır. Oluşan üç farklı katman, sırasıyla, asellüler plazma, plateletten zengin fibrin ve en altta eritrosit tabakadır. Asıl kullanılan trombositten zengin fibrin matriks, oldukça güçlüdür ve otolog biyomateryal olarak farklı sağlık alanlarında (oral, maksillofasyal ve plastik cerrahi gibi) kullanılabilir. ${ }^{[26]}$

PRP kullanımı ile ilgili iki temel tartışma söz konusu olabilir: Bunlardan ilki, santrifüjle sayısal olarak 3,5-4 kat arttırılmış trombositleri uygulama alanına verirken aktive edilip edilmeyeceğidir. Aktivasyon için trombin veya $\mathrm{CaCl}$ kullanılabilir. Yapılan araştırmalarda, trombositlerin aktivasyonu ile birlikte, 12 farklı sitokinin alfa granüllerinden ortama salındığı gösterilmiştir. ${ }^{[27]} \mathrm{Bu}$ ekstra 12 sitokin içinde; PDGF-AA, PDGF-BB, PDGF$A B$, TGF-B1, TGF-B2, EGF, IFNa, TNFa ve IL'ler (IL-4, IL-8, IL-13, IL-17) yer almaktadır. Bunlardan, özellikle yüksek konsantrasyonda salınan PDGF ve TGF'nin, pıhtıya bağlanarak yavaş bir ritm ile uzun süre salındığı 
Tablo 3. Ticari olarak bulunan farklı PRP hazırlama sistemlerinin sistematik özeti*

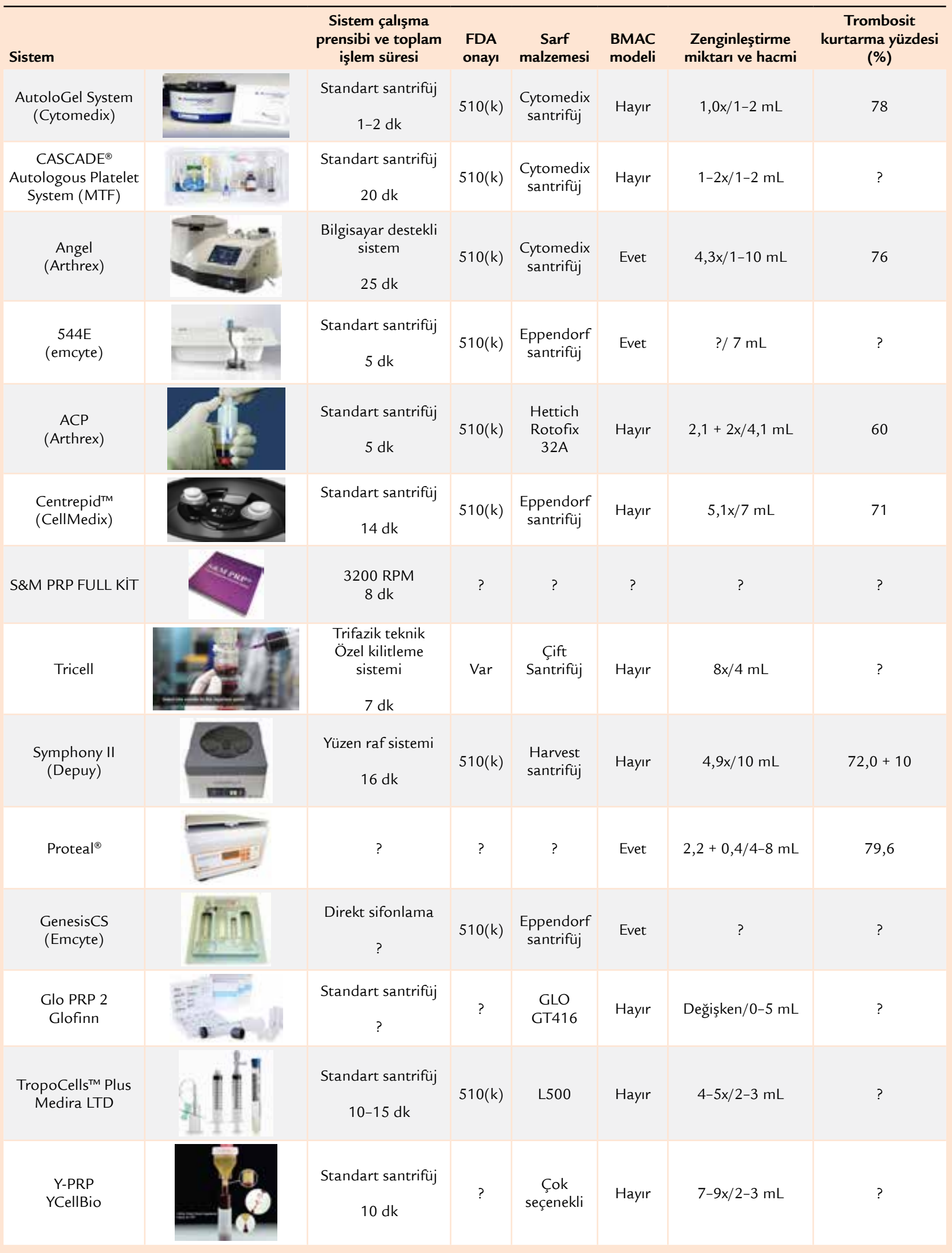


Tablo 3 (devam). Ticari olarak bulunan farklı PRP hazırlama sistemlerinin sistematik özeti*

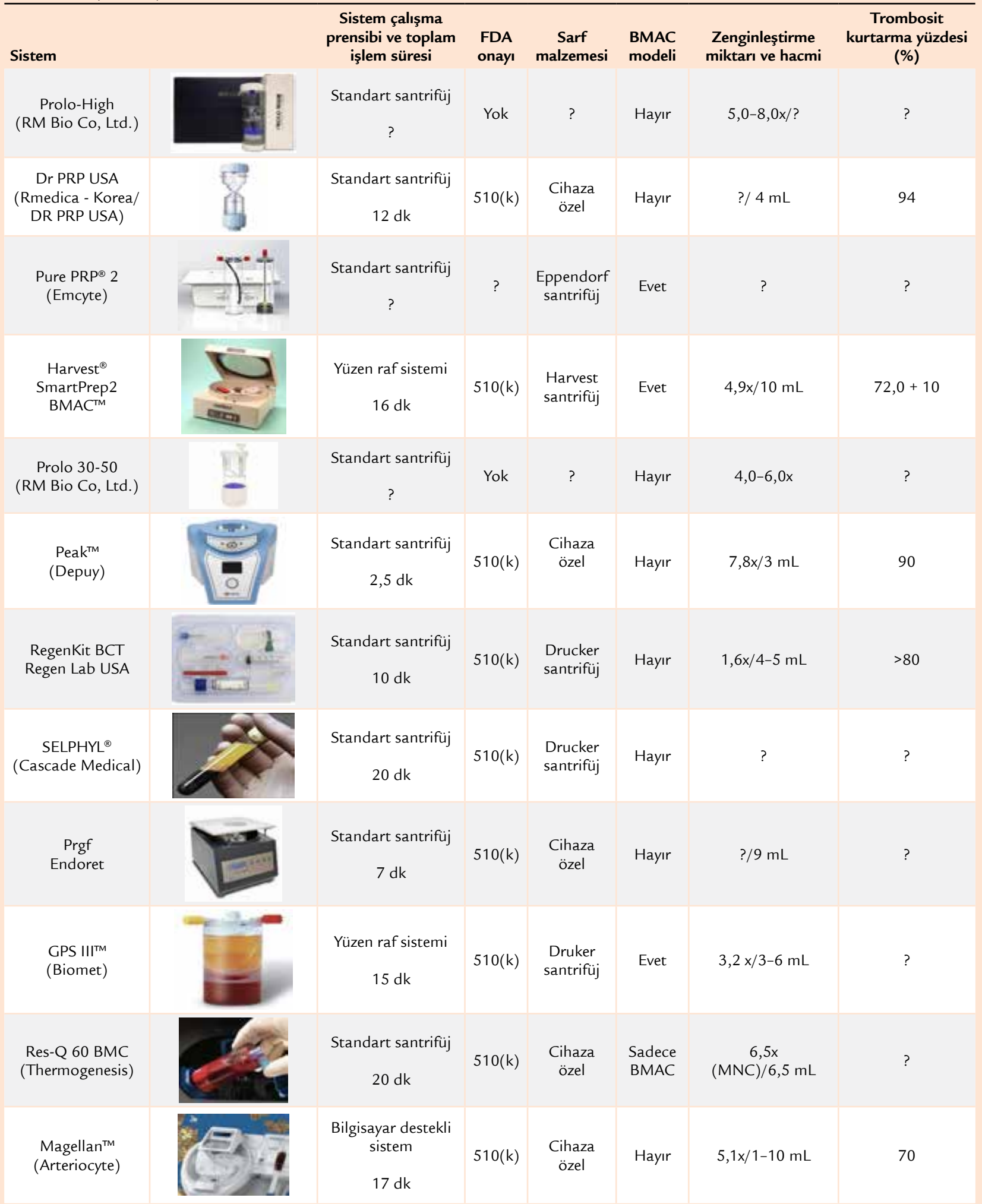

* Web sitelerinden, üretici prospektüslerinden, ilgili yayınlardan ve www.perfusion.com'dan uyarlanarak bir tablo haline getirilmiştir. Tablodaki bilgiler için kesin klinik değerlendirmelerin yapılması hekimin tecrübesi sonucunda olmalıdır. Bazı kullandığımız sistemlerde, prospektüs ve literatür bilgileri ile kendi elde ettiğimiz verilerin her zaman aynı olmadığını gözlemledik. BMAC: Kemik iliği aspirat konsantresi. 
Tablo 4. Başlıca trombositten zengin plazma ürünlerinin karşılaştırılması

\begin{tabular}{llllllll}
\hline Ürün & $\begin{array}{l}\text { Hazırlama yöntemi } \\
\text { (santrifüj) }\end{array}$ & $\begin{array}{l}\text { Örnek } \\
\text { miktarı }\end{array}$ & $\begin{array}{l}\text { Hazırlama } \\
\text { süresi }\end{array}$ & $\begin{array}{l}\text { Trombosit } \\
\text { miktarı }\end{array}$ & $\begin{array}{l}\text { Lökosit } \\
\text { miktarı }\end{array}$ & Uygulama şekli & Maliyet \\
\hline P-PRP & Yoğun & Az & Oldukça uzun & Mükemmel & Yok & Her bölgeye & Oldukça pahalı \\
L-PRP & Yoğun & Değişken & Uzun & lyi & lyi & Her bölgeye & Pahalı \\
P-PRF & Yoğun & Değişken & Uzun & lyi & Yok & Her bölgeye & Pahalı \\
L-PRF & Hafıf & Az & Kısa & lyi & lyi & Sadece açık yüzeylere & Oldukça ucuz
\end{tabular}

ve böylece mezenşimal kök hücreleri için çekici ve mitojenik etkiler gösterdikleri saptanmıştır. ${ }^{[42,43]}$ i kinci tartışma konusu ise, temel olarak L-PRP ve L-PRF karşılaştırılmasında hangisinin daha etkili olabileceğidir. ilk defa Choukroun ve arkadaşları tarafından 2001 yılında geliştirilen L-PRF'nin, dışarıdan eklenen trombin veya CaCl'ye ihtiyaç duymadığı, bu nedenle daha güvenli olabileceği ve L-PRP deki gibi çok farklı yaklaşımlardan uzak tek bir protokolünün olmasının önemli avantajları olabileceğidir (Şekil 8). ${ }^{[27]}$ Bu yöntemin dezavantajları ise, hazırlanan L-PRF'nin sınırlı hacimde olması ve donöre özgü olmasıdır.[44]

\section{TROMBOSITTEN ZENGIN PLAZMADAN BEKLENTILER}

Trombositlerdeki alfa granüller daha yakından incelendiğinde, hem pro-anjiyojenik hem de anti-anjiyojenik özellikler taşıyan proteinleri içerdikleri gözlenir. Hatta son çalışmalarda, bu farklı grupların farklı alfa granüllerde paketlendikleri gösterilmiştir. ${ }^{[45]}$

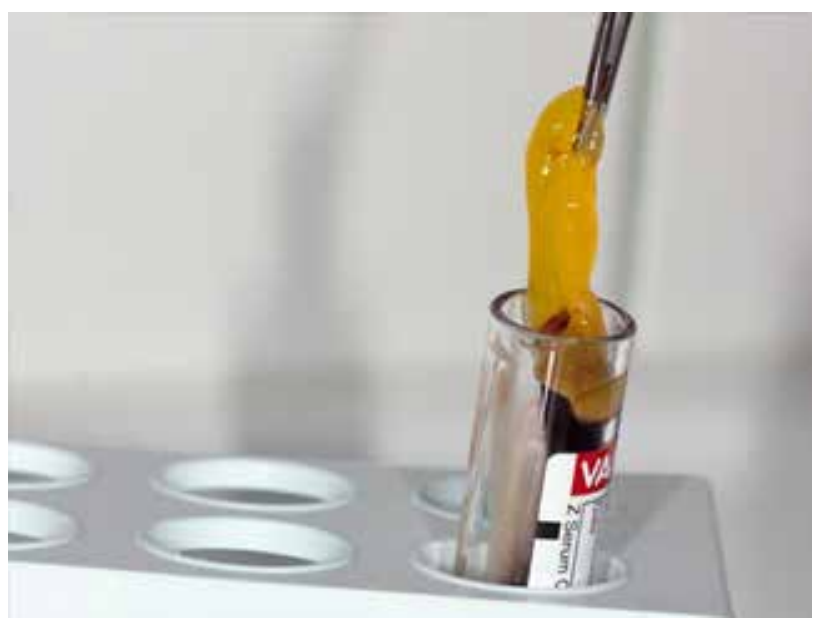

Şekil 8. 'Choukroun yöntemi’ ile laboratuvarda L-PRF hazırlanışı görülmektedir.
Trombositlerin bir diğer önemli özelliği, organizmanın kendini korumak için (host defense) virüslere, bakterilere, mantar ve hatta protozoalara karşı oynadıkları önemli roldür. Alfa granüller, mikrobiyosidal özellikli CXCL4, CXCL7 ve CCL5 ile kompleman C3 ve C4 prekürsörlerini de taşır.

PRP'den, gelecek yıllarda farklı görevler de beklenmektedir. Bunlardan ilki, doku mühendisliği alanıdır ki bu alanda, avasküler dokuların tasarlanması ile birlikte damarlanma ve hücre proliferasyonu önemli bir ihtiyaç olarak öne çıkmaktadır. ${ }^{[46]}$ ikinci farklı beklenti, PRP içinde yer alan lökositlere ait mediyatörlerin gelecekte kullanılabilecek olmasıdır. ${ }^{[26]}$ Ayrıca, yakın zamanın popüler konularından olan mezenşimal kök hücre çalışmalarında kullanılan fetal bovine serum yerine PRP'nin kullanılması ile, beklenmedik virütik hastalıkların bulaşmasının önlenebileceğidir. ${ }^{[47]}$

\section{SONUÇ}

"Ne ararsan kendinde ara" özdeyişinin doğrultusunda, kendi organizmamızı tanıdıkça daha yeni yöntem ve uygulamaların gerçekleşeceği bir dönem bizi beklemektedir.

\section{KAYNAKLAR}

1. Italiano JE, Hartwig JH. Megakaryocyte Development and Platelet Formation, in Platelets, 3rd ed. Amsterdam: Elsevier; 2007. p.63-85.

2. Josefsson EC, Dowling MR, Lebois M, Kile BT. The regulation of platelet life span. In: Michelson AD, editor. Platelets, 3rd ed. Amsterdam, The Netherlands: Elsevier/Academic Press; 2013. p.51-65.

3. Hoffmeister KM. The role of lectins and glycans in platelet clearance. J Thromb Haemost 2011;9 Suppl 1:35-43. Crossref

4. Schwertz H, Köster S, Kahr WH, Michetti N, Kraemer BF, Weitz DA, Blaylock RC, Kraiss LW, Greinacher A, Zimmerman GA, Weyrich AS. Anucleate platelets generate progeny. Blood 2010;115(18):3801-9. Crossref

5. Handagama PJ, George JN, Shuman MA, McEver RP, Bainton DF. Incorporation of a circulating protein into megakaryocyte and platelet granules. Proc Natl Acad Sci USA 1987;84(3):861-5. 
6. Winkler W, Zellner M, Diestinger M, Babeluk R, Marchetti M, Goll A, Zehetmayer S, Bauer P, Rappold E, Miller I, Roth E, Allmaier G, Oehler R. Biological variation of the platelet proteome in the elderly population and its implication for biomarker research. Mol Cell Proteomics 2008;7(1):193203. Crossref

7. Della Corte A, Tamburrelli C, Crescente M, Giordano L, D'Imperio M, Di Michele M, Donati MB, De Gaetano G, Rotilio D, Cerletti C. Platelet proteome in healthy volunteers who smoke. Platelets 2012;23(2):91-105. Crossref

8. Tranzer JP, Da Prada M, Pletscher A. Ultrastructural localization of 5-hydroxytryptamine in blood platelets. Nature 1966;212(5070):1574-5.

9. Siegel A, Lüscher EF. Non-identify of the alpha-granules of human blood platelets with typical lysosomes. Nature 1967;215:(5102):745-7.

10. Maynard DM, Heijnen HF, Horne MK, White JG, Gahl WA. Proteomic analysis of platelet alpha-granules using mass spectrometry. J Thromb Haemost 2007;5(9):1945-55. Crossref

11. Rendu F, Brohard-Bohn B. The platelet release reaction: granules' constituents, secretion and functions. Platelets 2001;12(5):261-73. Crossref

12. Ferrari $M$, Zia $S$, Valbonesi $M$, Henriguet $F$, Venera $G$, Spagnolo S, Grasso MA, Panzani I. A new technique for hemodilution, preparation of autologous platelet-rich plasma and intraoperative blood salvage in cardiac surgery. Int J Artif Organs 1987;10(1):47-50.

13. Sonnleitner D, Huemer P, Sullivan DY. A simplified technique for producing platelet-rich plasma and platelet concentrate for intraoral bone grafting techniques: a technical note. Int J Oral Maxillofac Implants 2000;15(6):879-82.

14. Blue Cross and Blue Shield Association. Recombinant and autologous platelet-derived growth factors as a treatment of wound healing and other conditions. Current Procedural Terminology of American Medical Association 2012.

15. Kon E, Buda R, Filardo G, Di Martino A, Timoncini A, Cenacchi A, Fornasari PM, Giannini S, Marcacci M. Plateletrich plasma: intra-articular knee injections produced favorable results on degenerative cartilage lesions. Knee Surg Sports Traumatol Arthrosc 2010;18(4):472-9. Crossref

16. Kon E, Mandelbaum B, Buda R, Filardo G, Delcoglian M, Timoncini A, Fornasari PM, Giannini S, Marcacci M. Plateletrich plasma intra-articular injection versus hyaluronic acid viscosupplementation as treatments for cartilage pahtology: from early degeneration to osteoaarthritis. Arthroscopy 2011;27(11):1490-501. Crossref

17. Filardo G, Kon E, Buda R, Timoncini A, Di Martino A, Cenacchi A, Fornasari PM, Giannini S, Marcacci M. Plateletrich plasma intra-articular knee injections for the treatment of degenerative cartilage lesions and osteoarthritis. Knee Surg Sports Traumatol Arthrosc 2011;19(4):528-35. Crossref

18. Spakova T, Rosocha J, Lacko M, Harvanova D, Gharaibeh A. Treatment of knee joint osteoarthritis with autologous platelet-rich plasma in comparison with hyaluronic acid. Am J Phys Med Rehabil 2012;91(5):411-7. Crossref

19. Mei-Dan O, Carmont MR, Laver L, Mann G, Maffulli N, Nyska M. Platelet-rich plasma or hyaluronate in the management of osteochondral lesions of the talus. Am J Sports Med 2012;40(3):534-41. Crossref

20. Zhu Y, Yuan M, Meng HY, Wang AY, Guo QY, Wang Y, Peng $\mathrm{J}$. Basic science and clinical application of platelet-rich plasma for cartilage defects and osteoarthritis: a review. Osteoarthritis Cartilage 2013;21(11):1627-37. Crossref
21. Campbell KA, Saltzman BM, Mascarenhas R, Khair MM, Verma NN, Bach BR Jr, Cole BJ. Does Intra-articular PlateletRich Plasma Injection Provide Clinically Superior Outcomes Compared With Other Therapies in the Treatment of Knee Osteoarthritis? A Systematic Review of Overlapping Metaanalyses. Arthroscopy 2015;31(11):2213-21. Crossref

22. Ornetti P, Nourissat G, Berenbaum F, Sellam J, Richette P, Chevalier X; under the aegis of the Osteoarthritis Section of the French Society for Rheumatology (Société Française de Rhumatologie, SFR). Does platelet-rich plasma have a role in the treatment of osteoarthritis? Joint Bone Spine 2016;83(1):31-6. Crossref

23. Riboh JC, Saltzman BM, Yanke AB, Fortier L, Cole BJ. Effect of Leukocyte Concentration on the Efficacy of Platelet-Rich Plasma in the Treatment of Knee Osteoarthritis. Am J Sports Med 2016;44(3):792-800. Crossref

24. Özgürtaş T, Utku B, Yıldız C. Platelet-Rich Plasma. In: Korkusuz F, editor. Musculoskeletal Research and Basic Science. Springer; 2016. p.283-8.

25. Özgürtaş T, Kahraman S, Erbil MK, Göksoy C, Çetin T, Atabey C, Demirtaş S. Deneysel siyatik sinir hasarında plateletten zengin plazma jel ve büyüme faktörlerinin etkisi. KBUD Kongresi, 2005, Antalya.

26. Martinez CE, Smith PC, Alvarado VAP. The influence of platelet-derived products on angiogenesis and tissue repair: a concise update. Front Physiol 2015. Crossref

27. Breen A, O'Brien T, Pandit A. Fibrin as adelivery system for therapeutic drugs and biomolecules. Tissue Eng Part B Rev 2009;15(2):201-14. Crossref

28. Lee DH, Ryu KJ, Kim JW, Kang KC, Choi YR. Bone marrow aspirate concentrate and platelet-rich plasma enhanced bone healing in distraction osteogenesis of the tibia. Clin Orthop Relat Res 2014;472(12):3789-97. Crossref

29. H. Namazi, A. Mehbudi. Investigating the effect of intraarticular PRP injection on pain and function improvement in patients with distal radius fracture. Orthop Traumatol Surg Res 2016;102(1):47-52. Crossref

30. Karaduman M, Okkaoglu MC, Sesen H, Taskesen A, Ozdemir $M$, Altay M. Platelet-rich plasma versus open surgical release in chronic tennis elbow: A retrospective comparative study. J Orthop 2016;13(1):10-4. Crossref

31. Kesikburun S, Tan AK, Yilmaz B, Yaşar E, Yazicioğlu K. Plateletrich plasma injections in the treatment of chronic rotator cuff tendinopathy: a randomized controlled trial with 1-year follow-up. Am J Sports Med 2013;41(11):2609-16. Crossref

32. Guney A, Akar M, Karaman I, Oner M, Guney B. Clinical outcomes of platelet rich plasma (PRP) as an adjunct to microfracture surgery in osteochondral lesions of the talus. Knee Surg Sports Traumatol Arthrosc 2015;23(8):2384-9. Crossref

33. Riboh JC, Saltzman BM, Yanke AB, Fortier L, Cole BJ. Effect of Leukocyte Concentration on the Efficacy of Platelet-Rich Plasma in the Treatment of Knee Osteoarthritis. Am J Sports Med 2016;44(3):792-800. Crossref

34. Napolitano M, Matera S, Bossio M, Crescibene A, Costabile E, Almolla J, Almolla H, Togo F, Giannuzzi C, Guido G. Autologous platelet gel for tissue regeneration in degenerative disorders of the knee. Blood Transfus 2012;10(1):72-7. Crossref

35. Laudy AB, Bakker EW, Rekers M, Moen MH. Efficacy of platelet-rich plasma injections in osteoarthritis of the knee: a systematic review and meta-analysis. $\mathrm{Br} J$ Sports Med 2015;49(10):657-72. Crossref 
36. Kanchanatawan W, Arirachakaran A, ChaijenkijK, Prasathaporn N, Boonard M, Piyapittayanun P, Kongtharvonskul J. Shortterm outcomes of platelet-rich plasma injection for treatment of osteoarthritis of the knee. Knee Surg Sports Traumatol Arthrosc 2016;24(5):1665-77. Crossref

37. Filardo G, Kon E, Pereira Ruiz MT, Vaccaro F, Guitaldi R, Di Martino A, Cenacchi A, Fornasari PM, Marcacci M. Platelet-rich plasma intra-articular injections for cartilage degeneration and osteoarthritis: single- versus doublespinning approach. Knee Surg Sports Traumatol Arthrosc 2012;20(10):2082-91. Crossref

38. Joshi Jubert $\mathrm{N}$, Rodríguez $\mathrm{L}$, Reverté-Vinaixa $M M$, Navarro A. Platelet-Rich Plasma Injections for Advanced Knee Osteoarthritis: A Prospective, Randomized, Double-Blinded Clinical Trial. Orthop J Sports Med 2017;5(2):2325967116689386. Crossref

39. Randelli P, Arrigoni P, Ragone V, Aliprandi A, Cabitza P. Platelet rich plasma in arthroscopic rotator cuff repair: a prospective RCT study, 2-year follow-up. J Shoulder Elbow Surg 2011;20(4):518-28. Crossref

40. De Vos RJ, Weir A, van Schie HT, Bierma-Zeinstra SM, Verhaar JA, Weinans H, Tol JL. Platelet-rich plasma injection for chronic Achilles tendinopathy: a randomized controlled trial. JAMA 2010;303(2):144-9. Crossref

41. Lebiedzinski R, Synder M, Buchcic P, Polguj M, Grzegorzewski A, Sibinski M. A randomized study of autologous conditioned plasma and steroid injections in the treatment of lateral epicondylitis. Int Orthop 2015;39(11):2199-203. Crossref
42. Catelas I, Dwyer JF, Helgerson S. Controlled release of bioactive transforming growth factor beta-1 from fibrin gels in vitro. Tissue Eng Part C Methods 2008;14(2):119-28. Crossref

43. Choukroun J, Adda F, Schoeffler C, Vervelle A. Une opportunite en paro-implantologie: le PRF. Implantodontie 2001;42:55-62.

44. Prakash S, Thakur A. Platelet concentrates: past, present and future. J Maxillofac Oral Surg 2011;10(1):45-9. Crossref

45. ItalianoJrJE, Richardson JL, Patel-Hett S, Battinelli E, Zaslavsky A, Short S, Ryeom S, Folkman J, Klement GL. Angiogenesis is regulated by a novel mechanism: pro- and anti-angiogenic proteins are organized into separate platelet alpha granules and differentially released. Blood 2008;111(3):1227-33. Crossref

46. Upputuri PK, Sivasubramanian K, Mark CS, Pramanik M. Recent developments in vascular imaging technique in tissue engineering and regenerative medicine. Biomed Res Int 2015;2015:783983. Crossref

47. Doucet C, Ernou I, Zhang Y, Llense JR, Begot I, Holy X, Lataillade JJ. Platelet lysates promote mesenchymal stem cell expansion: a safety substitute for animal serum in cell-based therapy applications. J Cell Physiol 2005;205(2):228-36. Crossref 